\title{
Pengambilan Keputusan Dalam Keluarga Sebuah Konsep dan Implementasinya
}

\author{
Oleh : Asmai Ishak
}

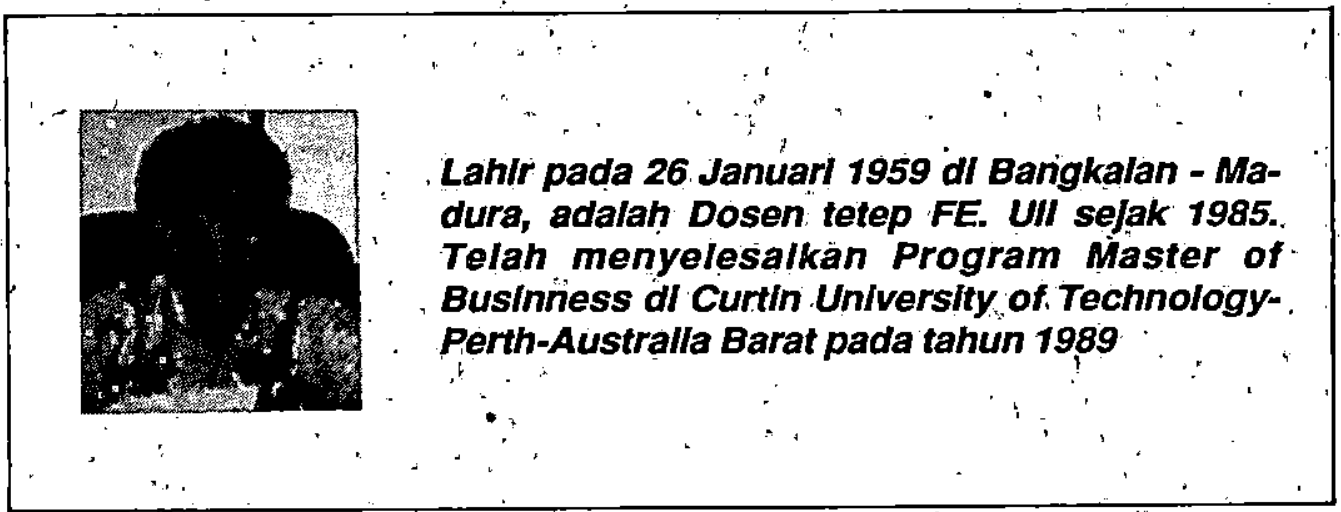

Pendahuluan

Perilaku konsumen merupakan bidang yang relatif baru dalam ilmu pemasaran yang akhir-akhir ini banyak mendapat perhatian, baik dari para akademisi maupun para praktisi. Hal ini sejalan dengan perkembangan orientasi konsep yang dipakai oleh para pengusaha dalam memasarkan hasil produksinya, yang bermula dari konsep produksi hingga konsep pemasaran yang berorientasikan sosial (societal marketing concept). Menurut konsep yang 'terakhir ini, kontinuitas perusahaan sangatlah tergantung pada' kemampuannya dalam memuaskan kebutuhan dan keinginan para konsumen dan masyarakat sekitamya
(Kotler, 1988, hal. 28). Dengan demikian merupakan suatu kewajaran jika para praktisi dan akademisi sangat memperhatikan " perubahan perilaku konsumen.

Dalam literatur perilaku konsumen banyak mengandung rujukan-rujukan yang semakin berkembang tentang rumah tangga sebagai unit yang relevan untuk mempelajari perilaku konsumén. Observasi sebab-akibat menunjukkan bahwa keluarga merupakan sebuah unit konsumsi dan pembuatan keputusan yang penting.

Sebagian besar pembelian barang yang terjadi dalam masyarakat seperti makanan, perumahan, dan transportasi adalah untuk 
dikonsumsi bersama. Seorang ayah/suami memutuskan lebih baik membeli mobil station wagon daripada mobil sport, yang sebetulnya lebih disukainya, karena dia sadar mempunyai banyak anak. Para suami membutuhkan dasi, pakaian, bahkan kaos kaki, tetapi keputusăn dari pembelian barang-barang yang dibutuhkannya itu sering dilakukan oleh isteri mereka. Keputusan-keputusan tentang pemilihan barang dan merk yang dilakukan oleh seorang ibu rumah tângga sering berdasarkan pesanan atau permintaan dari anggota keluarganya atau berdasarkan pendapatnya tentang apa yang disukai atau tidak disukai oleh keluarganya dán apa yang ia anggap baik untuk mereka.

Berdasarkan kenyataan, diatas, sebetulnya hanya sebagian kecil pembelian produk yang dilakukan oleh seseorang untuk kepentingan dirinya sendiri, Sebagian besar pengeluaran untuk konsumsi dalam masyarakat dilakukan untuk kepentingan bersama. Tulisan ini akan membahas tentang seluk beluk pengambilan keputusan pembèlian dalam keluarga dan implikasinya dalam penyusunan strategi pemasaran.

Peranan Keluarga dalam Pembuatan Keputusan Membeli.

Beberapa penelitian tentang perilaku rumah tangga dalam mengambil keputusan (Davis \& Rigaux, 1974; Kenkel, 1961; Qualls, 1987; Schaninger \& Allen, 1981) pada dasamya memfokuskan pada tiga pokok permasalahannya yang penting yaitu :(1) anggota keluarga yang membuat keputusan, (2) hasil akhir (outcomes) dari perilaku keputusan rumah tangga, (3) faktor-faktor yang mempengaruhi penetapan anggota keluarga yang membuat keputusan. Secara keseluruhan, penelitian tersebut mengisyaratkan bahwa beberapa perubahan telah terjadi dalam sikap dan orientasi perilaku laki-laki dan perempuan dalam keluarga masa kini.

Semula, penelitian Kénkel pada tahun 1961 menunjukkan bahwa dalam keputusan keluarga, tertentu, suami diidentifikasikan, sebagai pengontrol keputusan yang berkaitan dengan attribut fungsi dari produk yang akan dibeli sedangkan pihak istri lebih cenderung pada sisi estetikanya. Klasifikasi tersebut .berdasarkan pada keyakinan bahwa lakilaki pada dasamya-berorientasi pada pekerjaan (task-oriented) dan instrumentalis, 'sementara perempuan cenderung untuk lebih ekspressif seperti. yáng dimanifestasikan dalam sikap emosionalnya.Penemuan ini mengarahkan para pemasar untuk mentargetkan hasil produksinya, khusus untuk jenis kelamin tertentu, apakah laki-laki atau perempuan.

Namun demikian penemuan Kenkel ini disanggah oleh Haas (1980) yang kemudian diperkuat oleh Schaninger dan Allen (1981). Penemuan mereka menunjukkan bahwa telah terjadi beberapa perubahan dalam orientasi peranan yang berdäsarkan jenis kelamin (sex role orientation) pada sejumlah wanita yang bekerja. Sebagai contoh, Schaninger dan Allen mendapatkan perbedaan yang signifikan dalam perilaku belanja dan konsumsi antara keluarga yang ibu rumah tangganya bekerja dan konsumsi antara keluarga yang ibu rumah tangganya hanya diam di rumah.

Selanjutnya, beberapa penelitian mensinyalkan bahwa pengaruh suami dan istri dalam pengambilan keputusan 
ditentukan oleh tingkat struktur peranan keluarga dan pertanggung-jawaban keputusan itu sendiri. Pengaruh keluarga disini didefinisikan sebagai tingkat usaha suami dan istri untuk mendominasikan keputusan yang akan diambil. Sehubungan - dengan hal ini, Davis dan Rigaux serta Green dan Cunningham mengindikasikan bahwa tugas dan pertanggung-jawaban keputusan keluarga nampaknya didistribusikan berdasarkan jenis kelamin. Selain itu, Green dan Cunningham menambahkan bahwa beberapa perbedaan juga terjadi dalam perilaku pengambilan keputusan antara keluarga tradisional dan keluarga masa kini.

Perubahan peranan berdasarkan jenis kelamin (sex role) dan cara persepsi anggota keluarga pada peranan sangat mempengaruhi proses pengambilan keputusan. Rosen dan Granbois (1983) menemukan bahwa orientasi peranan berdasarkan jenis kelamin merupakan alat dalam mendefinisikan peranan pertanggungjawaban suami dan istri atas keputusan yang telah diambilnya.

Penemuan ini diperkuat oleh Qualls yang menyatakan bahwa terdapat hubungan yang relatif kuat antara orientasi peranan berdasarkan jenis kelamin (sex role orientation) dengan tingkat pengaruh keluarga, rujukan persetujuan, terjadinya konflik, dan hasil akhir dari keputusan. yang dibuat.

Berdasarkan penemuan-penemian diatas, sangatlah tidak tepat jika para pemasar masih tetap mengacu pada. pendapat Kenkel dalam memasarkan hasil produksinya. Adanya perubahan dalam perilaku pengambilan keputusan dalam keluarga memaksa para pemasar untuk tidak lagi terlalu mengklasifikasikan produk mereka untuk jenis kelamin tertentu. Selanjutnya, meskipun di negaranegara berkembang, seperti Indonesia, juga muncul wanita-wanita karier, pengaplikasian penemuan diatas masih perlu dipertanyakan atau paling tidak harus dilakukan dengan hati-hati. Hal ini mengingat kondisi sampel dari penelitianpenelitian tersebut sangat berbeda dengan kondisi yang ada dalam masyarakat di Indonesia. Seperti yang ditemukan oleh Asmai (1989) bahwa budaya dapat mempengaruhi perilàku pengambilan keputusan keluarga.

\section{Proses Pengambilan, Keputusan.}

Anggota keluarga cenderung untuk menspesialisasi dirinya pada produk yang mereka minati atau produk dimana mereka dianggap ahli. Setiap keluarga biasanya mempunyai struktur peranan yang berteda dalam menangani beberapá pengambilan keputisan pembelian. Namun demikian, secara garis besar, Davis dan Rigaux telah mengidentifikasikan bahwa struktur pengambilan keputusan dalam keluarga dapat dikelompokkan menjadi empat macam:

1. Wife dominat decision yaitu tipe keputusan yang sebagian besar diwarnai oleh pengaruh pihak istri daripada pengaruh anggota keluarga lainnya.

2. Husband dominat decision yaitu tipe keputusan yang sebagian besar diwarnai oleh pengaruh pihak suami daripada penganh anggota keluarga lainnya.

3. Syncratic decision yaitu tipe keputusan yang merupakan hasil kesepakatan suami dan istri. Dalam bentuk keputusan ini pengaruh suami dan istri adalah seimbang. 4. Autonomic decision. Tipe keputusan ini terjadi jika masing-masing suami dan istri secara individual bertanggung jawab untuk 
mengambil keputusan sesuai dengan nilai tradisionalnya.

Selanjutnya Davis dan Rigaux mengatakan bahwa pengaruh suami dan istri sangat bervariasi dalam setiap tahap proses pengambilan keputusan. Seorang istri, umpamanya berinisiatif mencari informasi yang relevan untuk pembelian baju suaminya, tetapi dia akan melibatkan suaminya dalam keputusan akhir sebelum pembelian itu dilakukan. Contoh ini memperlihatkan adanya perubahan dalam proses pengambilan keputusan dari wife autonomic pada tahap awal proses (pencarian informasi) menjadi syricratic di akhir proses pengambilan keputusan sangat dimungkinkan intensitas pengaruh suami dan iștri tidak selalu sama.

Selain fenomena-fenomena diatas, penelitian Davis dan Rigaux ini juga menunjukkan bahwa karakteristik produk mempunyai pengaruh dalam dominansi pengaruh. Umpamanya, keputusan pembelian jasa asuransi jiwa cenderung menjadi dominasi suami, sementara pengaruh istri nampak sangat dominan dalam pembelian peralatan dapur. Fenomena ini nampaknya masih tetap berlaku dalam keluarga masa kini, meskipun harus tetap disadari bahwa intensitas pengaruh suami atau istri agak berkurang.

Strategi Pemecahan Konflik.

Seperti yang telah disebutkan bahwa salah satu keputusan yang dihasilkan bersifat syncratic. Dari keputusan bersama ini akan muncul salah satu dari dua macam keputusan yaitu keputusan yang disetujui oleh salah satu atau semua keluarga. Konsesus terjadi jika seluruh anggota menyetujui keputusan yang telah ditetapkan, tetapi apabila terjadi ketidaksepakatan diantara anggota keluarga maka keputusan yang diambil harus bersifat akomodatif untuk memastikan bahwa semua pihak terpuaskan.

Tabel dibawah ini merupakan deskripsi yang dikembangkan oleh Davis (1976) tentarig strategi yang dipakai oleh keluarga dalam mencapai keputusan bersama.

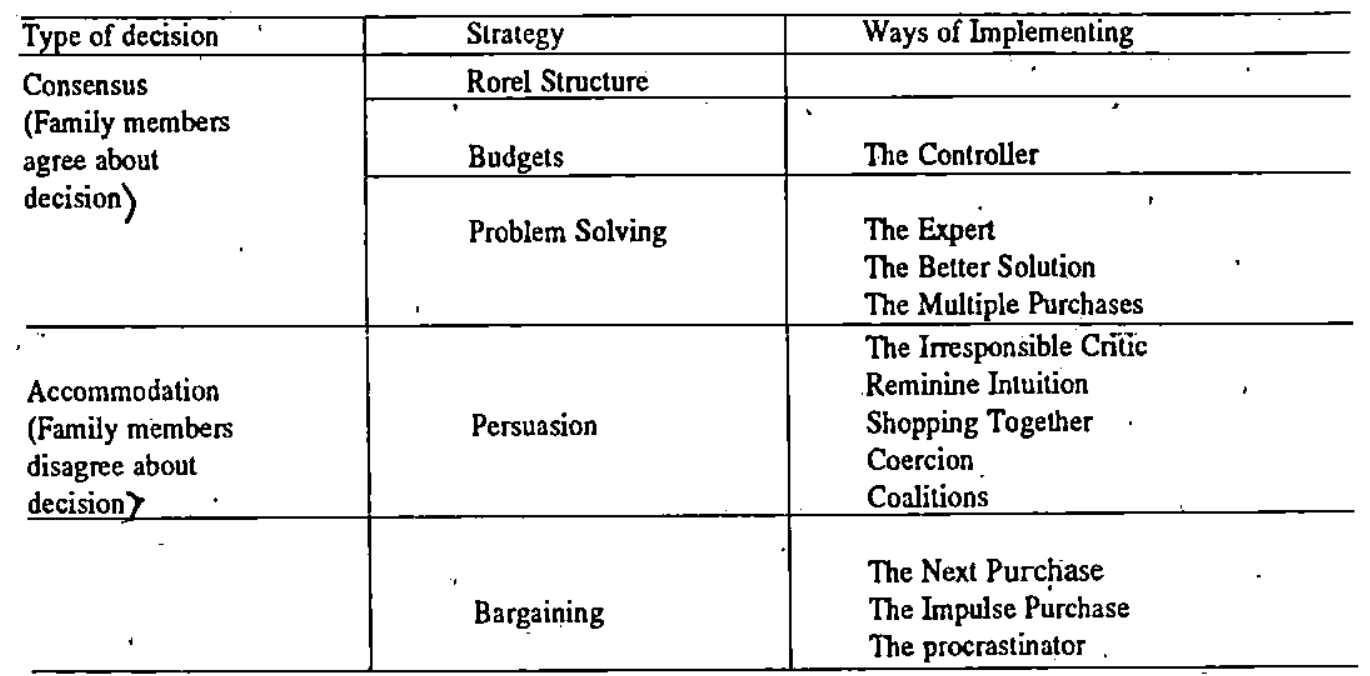

Sumber : Davis (1976), hal. 225. 
Dalam role structure strategy, salah seorang anggota keluarga menganggap dirinya adalah orang yang paling bertanggung jawab untuk mengambil -keputusan. Dia merasa dirinya mempunyai pengalaman dan pengetahuan yang cukup mumpuni (expert) untuk itu sehingga konsensus/kata sepakat dari anggota keluarga yang lain dengan mudah dicapai. Keputusan yang semacam ini sangat lazim dalam keluarga tradisional.

Budget strategy menghasilkan konsensus keluarga karena adanya batasan yang ditetapkan oleh controller. Pada umumnya yang dijadikan batasan oleh controller adalah harga dari produk yang akan dibeli. 'Umpamanya, pada . saat sebuah keluarga mempunyai dua pilihan type rumah yang akan dibeli, anggaran tertinggi yang telah ditetapkan sebelurinnya akan membantu untuk tercapainya kata sepakat/konsensus diantara anggota keluarga.

Selanjutnya, banyak keluarga yang menggunakan problem-solving strategy melalui diskusi diantara anggota keluarga untuk mencapai keputusan yang lebih baik, atau pembelian beberapa produk/merk sekaligus (multiple purchases) yang akan menyenangkan seluruh anggota keluarga. Sebagai contoh, setiap anggota keluarga sering mempunyai kepentingan dan keinginan yang berbeda dalam menentukan tujuan liburan. Si ibu menginginkan tempat yang agak sepi dan rilek, si ayah menginginkan lokasi yang memungkinkannya untuk tetap bermain tennis, sementara anak-anaknya yang sudah mulai menginjak remaja meninginkan lokasi yang ramai dikunjungi orang. Dalam kondisi yang demikian ini, pasti ada salah seorang anggota keluarga yang mempunyai banyak pengetahuan tentang lokasi rekreasi (expert) akan mempunyai pengaruh dalam pembuatan keputusan yang dapat menyenangkan semua pihak.

Untuk keputusan-keputusan yang sifatnya akomodatif, dimana kata sepakat diantara anggota tidak terjadi, strategi yang dipérgunakan pada umumnya adalah bersifat persuasif atau bargaining. Kedua strategi ini akan membantu mereka dalam meminimalkan atau mengurangi konflik yang terjadi.

Irresponsible critic terjadi jika ada anggota keluarga yang sadar bahwa dirinya tidak bisa mempengaruhi keputusan akhir, tetapi merasa bebas untuk mengkritik keputusan yang telah diambil. Jika keputusan akhir yang ditetapkan temyata salah, maka dia akan berkomentar, "Saya kan sudah bilang bahwa hai itu tidak mungkin". Tetapi sebaliknya apabila keputusan yang diambil temyata betul dia merasa dirugikan.

Feminine intuition merupakan strategi yang dipakai oleh anggota keluarga tertentu untuk melakukan pendekatan persuasif pada saat ada anggota keluarga yang lain akan tersinggung atas keputusan yang akan diambil. Pelaksanaan strategi ini tidak terbatas pada wanita.

Shopping together strategy adalah suatu cara pengambilan keputusan dengan mengajak orang lain ke lokasi, agar terpengaruh oleh suasana disekitarnya. Umpamanya, pada saat suami istri berselisih pendapat tentang mobil yang akan dibelinya, sang suami mengajak istrinya ke show room tempat penjualan mobil tersebut, untuk kemudian diajak untuk mengendarainya. Pengalaman nyata yang dialami oleh si istri dapat merubah persepsi atas mobil pilihan sang suami.

Coercion merupakan cara pengambilan keputusan yang relatif berbau pemaksaan 
daripada persuasif, mengingat dalam strategi ini terdapat unsur pemaksaan. Disini pengambil keputusan tanpa melihat apakah keputusannya dapat mengatasi konflik yang ada atau tidak.

Coalition adalah strategy yang didalamnya beberapa anggota keluarga bergabung untuk melawan anggota keluarga yang tidak setuju, dan sangat dimungkinkan pendekatan yang dipergunakan sangat persuasif.

Strategy bargaining memerlukan keterbukaan diantara anggota keluarga untuk saling memberi dan menerima (take and give). Beberapa cara pengambilan keputusan yang bisa dikatagorikan dalam strategi ini adalah the next purchase yang dalam pengambilan keputusannya terkandung janji bagi pihak yang mengạlah untuk mengambil keputusan pada pembelian berikutnya. Impulse purchase adalah strategi bargaining yang pengambilan keputusannya dilakukan dengan mem-fait accompli (memojokkan) pihak lain dengan harapan, mereka menerima keputusan tersebut tanpa terlalu banyak mengganggu. Strategi bargaining terakhir yang, sering dipakai untuk menghindari konflik adalah procrastination. Cara ini dilakukan dengan menunda pengambilan keputusan dengan harapan pihak-pihak yang terlibat melupakan apa yang menjadi ke-inginannya. Contoh yang paling sering dijumpai dari aplikasi cara ini adalah penolakan seorang ibu untuk memenuhi permintaan anaknya dengan mengatakan, "Mungkin besok, kita bicarakan lagi têntang hal itu" atau "tanyakan saja pada ayahmu".

\section{Peranañ Anak.}

Area yang kurang mendapat perhatian däri para peneliti adalah pentingnya anak- anak sebagai anggota keluarga dalam pengambilan keputusan pembelian. Fokus penelitian yang dilakukan pada umumnya tertabatas pada pengaruh antara suami dan istri, bukan keluarga secara keseluruhan: ,

Penelitian yang melibatkan/memperhitungkan kehadiran anak dalam keluarga menunjukkan bahwa pengambilan keputusan pada keluarga yang mempunyai anak berbeda dengan pengambilan keputusan pada keluarga yang tanpa anak (Filiatrault dan Richie, 1980). Meskipun anak-anak tidak berperanan secara lansung dalam pengambilan keputusan, tetapi kehadiran mereka dapat mengubah struktur pengaruh orang tuanya. Peranan potensial mereka dalam mempengaruhi keputusan keluarga adalah dengan cara mengadakan aliansi dengan ayah atau ibunya untuk mémbentuk kelompok mayoritas.

Selanjutnya, penelitian yang memfokuskan interaksi antara orang tua dan anak' mendapatkan bahwa pengaruh anak dalam' pengambilan keputusan semakin meningkat sejalan dengan peningkatan umur, kèmampuan dalam memberikan alasan pembelian yang logis, dan keinginan mereka untuk melakukan protes pada.saat permintaannya tidak terpenuhi (Ward and Wachman, 1972).

Semakin besar tingkat kemandirian anak-anak sebagai akibat kemajuan pendidikan, semakin moderatnya para orang tua, dan semakin meningkatnya jumlah keluarga karier (ayah dan ibú samasama bekerja) yang memberi tanggung jawab lebih pada anaknya, mengakibatkan anak-anak semakin mempunyai kesempàtan untuk ikut berbicara dalam keluarganya. Dalam beberapa hal, karena perkembangan teknologi yang cepat, anakanak mem̈punyai pengaruh yang cukup 
signifikan dalam pembelian beberapa macam produk yang mereka lebih tahu dari pada orang tuanya, umpamanya pembelian sepeda motor, computer game (Assael, 1987, hal. 410).

\section{Implikasi Pemasaran.}

Beberapa kesimpulan yang dapat diambil dari uraian diatas adalah bahwa telah terjadi perubahan yang cukup mendasar dalam konsep tradisional tentang pengambilan keputusan dalam keluarga selama dua dekade terakhir. Perubahanperubahan ini mengharuskan perusahaan untuk tidak hanya menggunakan konsep keluarga tradisional dalam memasarkan hasil produksinya. Pemahaman akan kecenderungan baru ini akan membantu para pengusaha dalam mengembangkan strategi pemasarannya baik dalam hal segmentasi pasar, formulasi strategi promosi, dan aspek pemasaran lainnya.

Faktor-faktor demografi yang paling relevan untuk diperhatikan oleh para pemasar adalah adanya perubhaan orientasi peranan pria dan wanita dalam keluarga, jumlah keluarga kecil (dua anak cukup), meningkatnya peranan anak dalam pengambilan keputusan, dan semakin memudarnya ikatan-ikatan keluarga tradisional. Khusus untuk menghadapi perubahan peranan pria dan wanita sebagai konsekwensi dari semakin banyaknya wanita (ibu rumah tangga) karier, pengusaha Indonesia harus hati-hati dalam mengadopsi strategi pemasaran yang telah dilakukan pengusaha di negara maju yang dinilai berhasil. Hal ini, mengingat kondisi kebudayaan termasuk income per capita, yang berbeda. Salah satu contoh adalah adanya peranan pembantu di Indonesia yang dapat menggantikan peranan ibu rumah tangga di saat mereka sedang bekerja di kantor. Hal ini akan menghambat pemasaran produk konsumsi yang bersifat "instant" yang mengutamakan kecepatan memasak.

Akhimya, pelajaran yang sangat penting bagi para pemasar adalah perlu disadarinya bahwa struktur pengambilam keputusan dalam keluarga adalah dinamis baik dalam kaitannya dengan waktu, keluarga secara individual, maupun tahaptahap dalam. proses pengambilan keputusan itu sendiri. Konsekwensinya, strategi pemasaran yang dikembangkan harus selalu diadaptasikan dengan perubahan kondisi yang ada demi tercapainya maksimalisasi kesempatan.

\section{Daftar Pustaka}

Asmai Ishak (1989), Husband-Wife Influence in The Purchase Decision-Making for Some Durable Goods", Thesis.

Assael, H. (1987), Consumer Behavior and Marketing Action, PWS-KENT Publishing Co., Malaysia, Edisi Ketiga.

Davis, H.L. (1976), "Decision Making Within Household", Journal of Consumer Research, Vol. 2, Maret, hal. 241-260.

Davis, H.L. Dan Rigaux, B.P. (1974), "Perception of Marital Roles in Decision Processes", Journal of Consumer Research, Vol. 1, Juni, hal. 51-62.

Filiatrault, P. dan Ritchie, J.R.B. (1980), "Joint Purchasing Decision : a Comarison of Influence Structure in Family an Couple Decision-Making Units", Journal of Consumer Research, Vol, 7, September, hal. 131-140.

Green, R.T. dan Cunningham, I.C.M. (1975), "Feminine Role Perception and Family Purchasing Decisions", Journal of Marketing Research, Vol. 12, Mei. Hal. 325-332.

Haas, L.'(1980), "Roles haring Couples : A Study of Egalitarian Marriages", Family Relations, Vol. 29, Júli, hal. 289-296. 
KenkeI, W.F. (1961), "Husband-Wife Interaction in Decision Making and Decision Choice", The Journal of Social Psychology, Vol 54.

Kotler, P. (1988), Marketing Management : Analysis, Planning, Implementation, and Contoll, Prentice Hall Inc., U.S.A., Edisi Keenam.

Qualls, W (1987) "Household Decision Behavior : The Impact of Husbands and Wives Sex Role Orientation", Journal Consumer Research, Vol. 14, September, hal. 264278.

Rosen, D.L. dan Granbois, D.H. (1983),
"Determinant of Role Structure in Family Financial Mahagement", Journal Consumer Research. Vol. 14, September, hal. 253-258.

Schaninger, C.M. dan Allen, C.T. (1981), "Wives' occupational Status As a Consumer Vehavior Construct", Journal of Consumer Research, Vol. 8, September, hal. 189-196.

Ward, S dan Wackman, D.B. (1972), "Children's Purchase Influence Attempts and Prental Yielding", Journal of Marketing Research, Vol. 9, Agustus. hal. 316-319. 